\section{Overseas Science Students' Association}

The Overseas Science Students' Association was formally instituted at a meeting in London on March 19, and about a hundred members have already joined. The proposal that such an Association should be formed was adopted at an earlier meeting on February 27 when Sir Harold Spencer Jones, the Astronomer Royal, addressed a number of overseas science students at the Society for Visiting Scientists. The objects of the Association are to bring graduate science students from overseas into contact with the scientific life of Great Britain and to bring such students into contact with one another. It is affiliated to the Society for Visiting Scientists, Ltd., where its meetings will be held. The Association proposes to fulfil its objects by arranging scientific meetings and visits to places of scientific interest and by other means. The executive committee has been elected as follows: President, W. J. De Coursey (Canada); Secretary, P. Sen (India); Treasurer, Dr. J. Pepys (South Africa); Members of Committee, P. Mildner (Yugoslavia), Miss E. H. Nelson (United States), Miss M. E. De Jager (South Africa), M. Ramasamy (Ceylon), Dr. Sutarman (Indonesia) and J. Thabit (Iraq). Further details can be obtained from P. Sen, c/o Society for Visiting Scientists, Ltd., 5 Old Burlington Street, London, W.1.

\section{Institute of Petroleum : New Officers}

Aт the annual general meeting of the Institute of Petroleum, held on April 24, at 26 Portland Place, London, W.1, Mr. H. S. Gibson was elected president for the session 1952-53. Mr. Gibson, who is managing director of the Iraq Petroleum Co., Ltd., and associated companies, was responsible for the negotiations which resulted in the recent signing of the new agreement between the Government of Iraq and his companies. Previously, he had been general fields manager in Persia for the Anglo-Iranian Oil Co., in which organization he had been since 1928. He was awarded the Redwood Medal of the Institute of Petroleum in 1947, in which year he also received the C.B.E. The following elections were also made at the meeting. Vice-Presidents: H. Hyams, of the Product Development and Research Department, Shell Petroleum Co., Ltd.; H. E. F. Pracy, general manager, Trimpell, Ltd.; and R. B. Southall, director, National Oil Refineries, Ltd. New Members of Council : A. J. Goodfellow, chief chemist, Carless, Capel and Leonard, Ltd. ; E. C. Masterson, manager of the Oil Department, Kuwait Oil Co., Ltd. ; A. R. Stark, in charge of lubricating oil and bitumen manufacture, Anglo-Iranian Oil Co., Ltd.; and W. H. Thomas, analytical and technical information officer, Sunbury Research Station, Anglo-Iranian Oil Co., Ltd.

\section{Announcements}

SIR CyRIL Fox, formerly director of the National Museum of Wales, has been awarded the Gold Medal of the Society of Antiquaries, for his distinguished services to archæology.

Dr. A. L. Morrison has been appointed director of research of the Research Laboratories of Roche Products, Ltd., of Welwyn Garden City, in succession to Dr. F. Bergel, who has been elected to the chair of chemistry in the Institute of Cancer Research, University of London.
Dr. Evani KondaIaH, who for the past three years has been working with Prof. Kai Siegbahn at the Nobel Institute, Stockholm, has been appointed a Scholar at the Australian National University, Canberra, and will work with Prof. E. W. Titterton in the Department of Nuclear Physics.

Dr. D. L. GuNN has been seconded to be director of the International Red Locust Control Service, the headquarters of which are at Abercorn, Northern Rhodesia. Since 1946 he has been principal scientific officer at the Anti-Locust Research Centre, London, and before that he was senior lecturer in zoology in the University of Birmingham.

THE Weizmann Prize, awarded by the municipality of Tel Aviv, is given for original research work, judged to be the most distinguished of that produced from and in association with Israel, and published not more than two years previously ; the first award was made in 1949. Recently two awards have been made, one to $\mathrm{Y}$. Dostrovsky, J. Gillis and D. R. Llewellyn, of the Weizmann Institute, Rehovoth, and University College, London, for their work on the separation of isotopes, and the other to $\mathrm{L}$. Bichovsky-Slomnitzki for her work on the influence on bacteria of aromatic diamidines and polyamines.

A symposium on "Micro-Waves and their Relation to Optics" will be held in Milan during June 9-11. The symposium is sponsored by the International Commission on Optics and the International Union of Pure and Applied Physics. It is being organized by the National Research Council of Italy and by the Italian Society of Physics. Further information about the symposium can be obtained from Prof. E. Perucca, Polytechnico, Turin.

THE First International Congress of Dietetics will be held in Amsterdam at the Royal Tropical Institute, 63 Mauritskade, during July 7-11. The Congress, which is being organized by the Netherlands Association of Dieteticians, will have as its principal aim the discussion of methods whereby the science of nutrition and dietetics may best be applied to the public wellbeing. Further information can be obtained from the Council of Nutrition, 42 Koninginnegracht, The Hague.

A sUMmer course in techniques and applications of the electron microscope will be given by the Laboratory of Electron Microscopy of the Department of Engineering Physics, Cornell University, during June 16-28. The course is designed for research workers in institutions or industry who have recently entered the field of electron microscopy or who are planning to undertake research problems involving applications of the instrument. Further details can be obtained from the director of the course, Dr. Benjamin M. Siegel, Department of Engineering Physics, Rockefeller Hall, Cornell University, Ithaca, N.Y.

Erratum. Dr. J. D. H. Strickland writes: "In the communication under the title 'Use of Ion Exchange Resins to determine the Charge of an Ion in Aqueous Solution' in Nature of April 12, p. 620, an error occurs in equation (3), which should read:

$$
\log \frac{k_{1}}{k_{2}-k_{1}}=\frac{n_{2}}{n_{1}} \log C_{B}+\log \left(\frac{V}{\sqrt[n_{1}]{K_{c} \cdot u \cdot \bar{C}}}\right) .
$$

This in no way vitiates the general conclusions". 